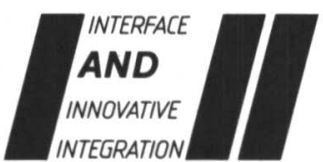

\title{
高速 船
}

\section{超高速全没翼型水中翼船“ジェットフォイル”*}

長谷川 康 夫** $^{* *}$

Super High Speed Fully Submerged Hydrofoil "Jetfoil"*

by Yasuo Hasegawa**

キーワード：ジェットフォイル, 全没翼型水中翼船, ガスタービンエン ジン, ACS

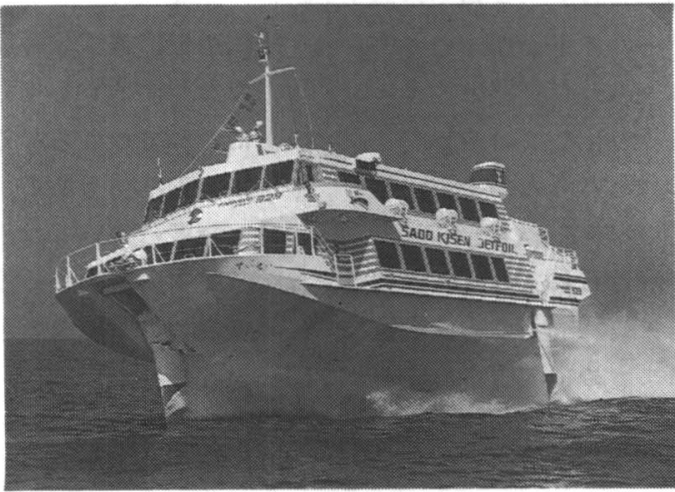

写真 1 川崎ジェットフォイル 10 号艇“すいせい”

1.はじめに

近年, 経済発展や余暇利用の多様化に伴い, 各種 交通機関における快適化，高速化に対するニーズが とみに高まってきている，旅客船分野においても例 外ではなく，快適性，高速性にすぐれた超高速船の 導入機運が盛り上がりを見せている。

高速船はその重量支持方式により, 浮力支持, 空 気圧力支持および揚力支持方式に大別できる. 全没 翼型水中翼船「ジェットフォイル」は揚力型に属し, 文字通り水中翼を海中に全没させ，その揚力により

*原稿受付 平成 4 年 7 月 22 日 川崎重工業株式会社 Kawasaki Heavy Industries, Ltd.
船体を持ち上げて航行する。このため波浪の影響を 受けず，速くて，摇れない画期的な旅客船でる.

以下にこのジェットフォイルの概要を紹介させて いただく。

\section{2. 主 要 目}

本船の主要目を以下に示す。

全長（水中翼を上げた状態）

$30.3 \mathrm{~m}$

全長（水中翼を下げた状態） $27.4 \mathrm{~m}$

垂線間長 $24.0 \mathrm{~m}$

型幅 $8.5 \mathrm{~m}$

最大幅 $9.1 \mathrm{~m}$

型深さ (メインデッキ) $2.6 \mathrm{~m}$

満載喫水（水中翼を下げた状態）約 $1.5 \mathrm{~m}$

最大喫水（水中翼を上げた状態）約 $2.2 \mathrm{~m}$ 
最大喫水（水中翼を下げた状態）

総トン数

最大搭載人員

翼走速力

航続距離
約 $4.9 \mathrm{~m}$

約 170 トン

約 270 名

約 45 ノット

約 300 海里

\section{3. 一般 配 䇫}

本船にはメインデッキ,アッパーデッキ、ハウス トップの各甲板が設けられており，メインデッキ下 は水密隔壁により 16 の区画に分けられている.メイ ンデッキ下の区画は後部よりガスタービン室, 減速 機・ウォータージェット推進機室, 後部補機室, 燃 料タンク，前部補機室がいずれもコンパクトに配置 されており，水密隔壁はいずれの 2 区画に浸水して も，安全なように配㯰されている。

客室は上部客室と下部客室の 2 㿉から成り, 約 270 名の乗客及び乗員を乗せることができる，各客 室の舷側および下部客室の前方には大きな角空が設 けられていて，十分なクリアーハイト，ゆったりと したエントランス，階段スペース及び通路と相まっ て，明るく広々とした空間を作り出している.

客室の椅子は軽量であるのはもちろんのこと, 坐 り心地のよいものを採用している.

上部客室の前方に操縦室が設けられており，操綐 に必要なすべての機器・計器・警報等がこの操縦室 内にコンパクトかつ機能的にまとめて配置されてお ク，さながら航空機のコックピットの様相を呈して

いる．また，通常の状態ではすへてのシステムが操 縦室より制御できるようになっている.図1に一般 配置図を示す。

\section{4. 船体構造・材貿}

船体構造材料は軽量化のため5456アルミニウム 合金，ストラットおよびフォイルには高強度及び耐 食性のすぐれた析出硬化型ステンレス鋼 (15-5 PH) やチタン合金が使用されている、アルミニウム合金 の溶接はティグ溶接法とミグ溶接法を併用し， 15-5 $\mathrm{PH}$ 鋼の溶接はティグ溶接, ミグ溶接,プラズマアー ク溶接及び電子ビーム溶接を併用している ${ }^{1)}$.

15-5 PH 鋼は溶接部の材料特性を母材と同等に 確保するために溶接組立終了後に固溶化および時効 の熱処理を必要とする材料でありその施工および品 質管理が難しい材料である. 最近この 15-5 PH 鋼と 同程度の性能を有し溶接後の熱処理が不要である新 材料が開発された2!。

船体の構造方式は縦助骨方式であり，溶接接合を 極力少なくするために，押出形材が多用され，また 板材についてはさらなる軽量化のために減肉加工を 施している部材もある。

船体強度については,規則で要求される強度の他， 荒天航海中に遭遇する波による船底への衝撃荷重や 㗨急着水時の衝撃荷重等に対し十分な強度を有する 様に設計されている。船体中央断面図を図 2 に示す。 この他, 内装材についても, 航空機でよく使用さ
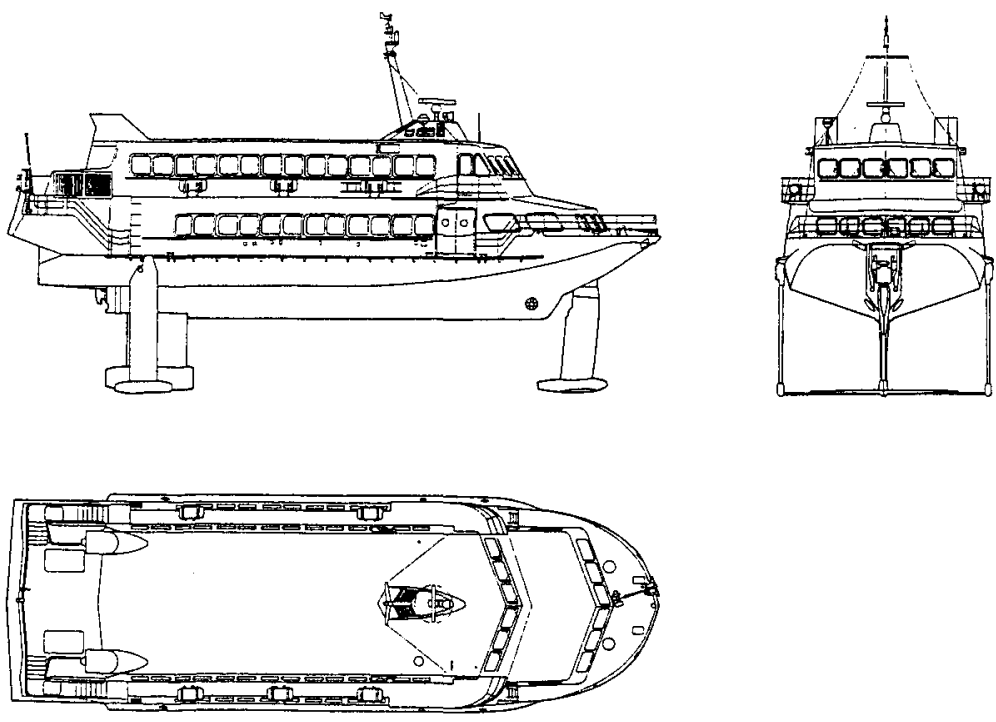

図 1 一般配置図 


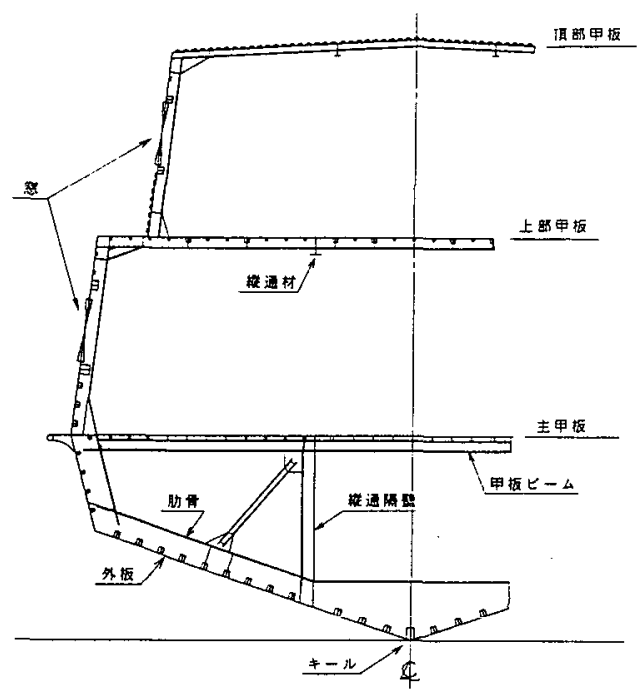

図 2 船体中央断面図

れている軽くて強いハニカム材が使われている.

\section{5. ストラット (支柱) およひフォイル （水中垡）}

本船の前部及び後部には全没翼型水中翼が設けら れており，翼走中はこれらのフォイルにより発生す る揚力で船体を海面上に持ち上げて航走する.

これらのフォイルと船体とはストラットと呼ばれ る翼型断面を有した支柱で結合されている．前部ス トラットは 1 本でフォイルとはちょうど逆 T字形 に結合されている、一方, 後部ストラットはストラッ トを下げた状態では海水吸入口をも形成する中央の ストラットと左右舷側のストラットの計 3 本がフォ イルに接合されている。

フォイルとストラットは水深が許せば下ろした状 態が本船にとって通常の航行状態であるが, 水哚が 浅い個所では油圧アクチュエーターにより両方のス トラットおよびフォイルを上げて航行することもで き,さらに艇走時の操縦性能が重視される場合には 前部ストラットだけを下ろして航行することもでき る. 各ストラットの上げ下ろしに要する時間はおよ そ1〜2 分である(図 3 参照)。

前部ストラットを下ろした状態で航行する場合, これを通常船舶の舵のように回転させることがで き, 艇走中は舵として，そして翼走中は傾斜釣合い 旋回(バンクターン)中の水流に合い, サイドフォー スがほとんど加わらないよう工夫されている。また， 水中浮遊物や大形水中生物と万一衝突した時に，ス
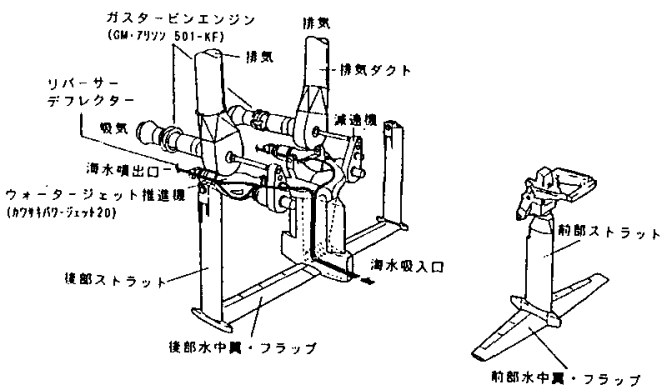

図 3 水中翼と推進システム

トラットや船体を保謢する目的で, 前部ストラット には衝突エネルギーを吸収するショックアブソー バーか゚，そして後部ストラットにはシアーピンがそ れぞれ設けられており，安全性の面でも十分な配虑 がなされている。

\section{6. ウォータージェット推進システム}

本船の推進力としては, 翼走中, 艇走中ともウォー タージェット推進機が生み出すウォータージェット を利用している，本船の推進システムは左右舷それ ぞれ独立の 2 系統のシステムから成り，それそれの システムはガスタービン，滅速ギア及びウォーター ジェット推進機から構成されている(図 3 参照). 従って，もし，いずれか片舷のシステムが故障した 場合でも，牫るシステムにて艇走航行することがて きるようになっている。

\section{1 ガスタービン}

ガスタービンはゼネラルモータース・アリソン社 製の $501 \mathrm{KF}$ 型で, C-130(ハーキュリーズ)輸送機, P 3C 対潜吵戒機, その他の航空機に使用されてい るジェットエンジンの船舶への転用型であり, 数多 くの実績を有している。またこのガスタービンは 軽量かつコンパクトであるにも拘らず，毎分 13,120 の高回転数て 3,800 馬力を生み出す警異的なパワー を持っている。

ガスタービンはコンプレッサー, 燃焼室, ガスジェ ネレーターおよびパワータービンから構成されてお り，付属システムとして，始動装䈯，燃料供給シス テム, 潤滑油供給システム等が装備されており, 燃 料油としては軽油を使用する。この他，デミスター 付空気取り入れダクトとタービン給気スクリーンお よび排気ダクトが各ターピンに設けられている。

14 段軸流式コンプレッサーはエンジン内へ空気 を取入れ，燃焼室での使用に必要な圧力まで空気を 王縮する。然焼室は6 個のライナーチューブから成 


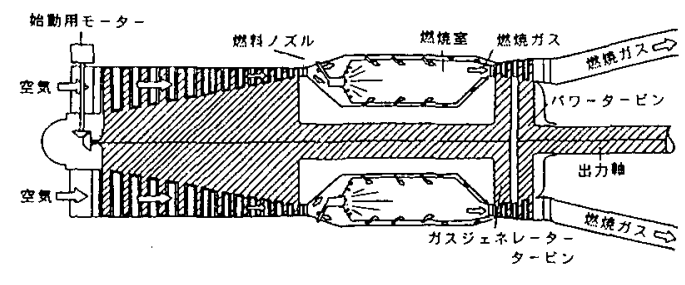

图 4 ガスタービンエンジンの構造

りこのライナーチュープの 1 次区域で圧縮空気と 燃料の混合扝よび連続した燃烵が行われる。2段ガ スジェネレータービンは高温ガスのエネルギーを， コンプレッサーを駆動する軸力へ変換する，パワー タービンは，減速ギアを通じてウォータージェット 推進機を駆動する動力源であり，高温ガスから動力 を取り出す 2 段の軸流タービンから成る。排ガスは 排がスコレクターおよび排気ダタト，煙笑を通って 船外人放出される (図 4 参照).

操䋛室コンソールには推進プラントの運転・制 御・監視用のパネルが配備されて扔り，がスタービ ンエンジンは操縦室より遠隔㙅作され運転中機関室 無人である。エンジン始動は，操縦室コンソールに 組み込まれている起動ボタンを押した後は, 自動起 動回路により自動的に進行する.エンジン停止は， 同様に停止ボタンを押しエンジン付きの燃焼弁を閉 とすることにより行われる.

また，各エンジンに対し1個のスロットルレバー が装碏されており，このレバー操作によってエンジ ン回転数を制御する。これらのレバーは両方同時に 片手で位置を決めることができるように配置されて いる。

\section{2 隇速キア}

減速ギアは，シングル・ヘリカル型で，ガスター ピンの出力軸の回転数を, ウォータージェット推進 機の回転数にまで, 減速比 6.37 で減速するものであ る.

\section{3 ウォータージェット推進機}

ウォータージェット推進機は，インデューサー, インペラー, ポンプ軸, ハウジング（内部点検孔付 き)、インデューサーライナ,ノスルから構成されて 抢り,1台当り毎分 $90 \mathrm{~m}^{3}$ の高圧水をジェット流とし て吐出する能力を有するものである.

ウォータージェット推進機へ取り入れる海水は, 後部ストラットを下げた状態では後部中央ストラッ ト下部から，また，ストラットを上げた状態では船 底吸水口から取り入れられ，Y 型ダクトにより各舷
の推進機に導かれ，推進機により加速されてノズル より船外に噴射される．ウォータージェット推進機 にゴミが吸入されるのを防ぐため，船底吸水部にゴ ミ排除用のインレットグリルが取り付けてあり，王 縮空気によるゴミ排除装置（エアーブローダウンシ ステム)を設けてある。

ウォータージェット推進機のノズル後方には, ウォータージェットの噴射方向を左右に偏向させる テフレクターと，噴射方向を前後逆転させるリバー サーが取りつけられておう, 艇走時の進路変更, 後 進を行う。これらは油圧アクチュエーターにより作 動する。

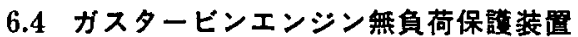
ガスタービンエンジンには無負荷保護システムが装 備されている。これは，ウォータージェット推進機 への吸水口が海面に露出するなど，吸水が少なく なって推進機の負荷が急激に低下した時, タービン のオーバースピードによるシャットダウンを防ぐた め, 推進機入口压の減少を検出し, 自動的にガスター ビンの回転数をアイドル回転数まで下げ，吸水口が 再び水中に入り推進機入口圧が上昇し始めると, 自 動的にガスタービンを元の設定回転数まで戻す一連 の過程を制御するシステムである。本システムは, 荒天時翼走の際に非常に有効な働きをする装置であ る.

\section{7. 自動姿勢制御装霓 $(\mathrm{ACS})^{3,4}$}

浮力により全重量を支える一般船とは異なり，掦 力で船体を支える本船にとって自動姿勢制御装置 (ACS-AUTOMATIC CONTROL SYSTEM) は 必要不可欠のシステムでありこの ACS 無くして は本船特有の素晴らしい乗り心地はあり得ないと 言っても過言ではない.

一般に船のモーションは下記の如く 3 つの直線遇 動と 3 つの回転運動に分けられる.

・サージ（前後直線運動）

・スウェイ (左右直線運動)

・ヒープ（上下直線運動）

・ピッチ（船の長さ方向の垂直面上の回転運動）

- ロール (船の幅方向の垂直面上の回転運動)

・ ヨー (水平面上の回転運動)

実際の船の連動はこれらが複雑に組み合わされる が,このうち, 本船ではサージとウェイを除く主要 な 4 つの運動を検知し，コントロールサーフェイス と称している 6 つの制御翼面（前部ストラット，前 
部フラップ, 4 組の後部フラップ)を制御しているの て，一般船に比へ，格段に乗り心地の面においてす ぐれていると言うことができる。

この ACSには自動的に船の姿勢を一定に保つた めのセンサーとして，船体の海面上の高さを検知す る高度センサーと船体のピッチ角及びロール角を検 出する重直ジャイロ，それと乗り心地改善のための センサーとして加速度計及びョーレイトジャイロが 装備されている。

このうち船体の姿勢制御に直接関連するセンサー およびACS 電源はフェイルセーフの設計思想に基 づき 2 重系になっていて，ひとつのセンサー，また は電源が故障しても安全に翼走を継続できるように 設計されている，万一，電源が 2 重故障した場合で も，安全に自動着水できるょうに工夫されている。

これらのセンサーの信号は絶えずコンピューター に送られ、へルム (舵輪) や翼梁度設定レバーの信 号と比較され，コンピューターがリアルタイムに最 適姿勢を計算しフラップおよび前部ストラットを駆 動する油圧アクチュエーターに対し最適姿勢に見 合った信号を出力し，船体の姿勢をコントロールす る。

\section{8. 操 䊀}

このようにACS がヘルム等の信号と海面状況， 加速度等を検知して，絶えず安定した船体姿勢を自 動的に保つように姿勢制御を行なっているので，離 水中および翼走中の操繸は極めて簡単で，觟走中に 翼梁度設定レバーをセットし，所定のスイッチを入 れた後スロットルを徐々に上げていくだけてよい。 船はある船速に達すると離水し始め，自動的に翼走 に移行する，通常翼走中はへルムを操作するだけて 良く，一定の針路をとる時はへティングホールド （オートパイロット）をセットすれば，完全に自動 連航となる。

翼走中の旋回は，ヘルムからの信号に応じて， ACS が後部フォイルの左舷側のフラップと右舷側 のフラップを互いに逆になるように動かす仕組みと なっておりその応答は非常に速い，例えば，左に旋 回する場合，左舷側のフラップを上向き（揚力が減 る）にし，右舷側のフラップを下向き（揚力が增え る）にする。この結果，船体は左舷を下にするよう に傾き，この傾斜により旋回する．傾斜角度は遠心 力を打ち消すょうに，すなわち，遠心力と重力の合 力が甲板面に垂直になるように ACS が制御する。
この時, 前部ストラットも水流に沿うように回転し， 他の船では見られない滑らかでダイナミックな傾斜 旋回（バンクターン）を生み出している。

荒天時においてもへルムと翼深度設定レバーを使 い, 波高 $3 \mathrm{~m}$ から $4 \mathrm{~m}$ の波でも影響を受けずほとん ど船速低下なく乗り切ることができる。

翼走時の停止はスロットルを下げ，タービン出力 を下げることで通常行なうが，非常の場合はこのス ロットルをフルリバースまで下げることにより，後 進力を発生させると共に，これと同時に前部フォイ ルの媣度が自動的に最哚となるように設計されてい て，船体を強制的に着水させることもできるように なっておりそその際の制動距離は自動車並みである。

解走中の操狱装置として, 前述のデフレクターと リバーサーが装備されている，また，前部ストラッ 卜を下げた状態ではこれを回して舵のように作用さ せることもできる。デフレクターと前部ストラット はヘルムにより，リバーサーはスロットルにより動 くようになっている。これらのデフレクターおよび リバーサーでウォータージェットの向きが自由に変 えられるばかりでなく，左右舷のタービン出力も変 更できるので, ウォータージェットの推力の大きさ そのものも変えられ，これらの組み合わせによりさ まざまな操繸をすることができる。

しかももっとも難しいと言われる離着岸時の操 船性を容易にするために，両方のデフレクターをあ る一定位置に固定するためのドッキングスイッチも 装備されていて，このスイッチを入れて，スロット ルを調整すると通常船船では難しい横移動やその場 回頭をすることができる.

\section{9. 電 氮 钤 備}

主電源として，AC $450 \mathrm{~V}, 60 \mathrm{~kW}$ のディーゼル発 電機が 2 台装倩されていて, 船内の必要負荷を賄っ ているがここのうち 1 台が故障した時ても推進や安 全に不要な負荷を切離すことにより，1台の発電機 でも翼走を継続することができるようになってい る.

ディーゼル発電機により発電された AC $440 \mathrm{~V}$ は エアコン装置, 潤滑油ポンプ等に, 変圧器を通した AC $100 \mathrm{~V}$ は照明機器や飲料水ポンプ等に, また, 変 圧器/整流器を通した DC $24 \mathrm{~V}$ は ACSをはじめと する各種制御機器, 計器, 非常灯, 通信機器等に給 電されている。

$\mathrm{AC}$ 電源が故障した際の非常用電源としてバッテ 
リーが設けられていて，重要な DC 機器に給電され るシステムとなっている.

\section{0. 夜 間航行}

交通機関の高速化の進展に伴い，超高速旅客船 （ジェットフォイル）の導入の活発化と併せて夜間 航行の要望が高まってきていることに鑑み、ジェッ トフォイルの夜間の高速航行に関する安全上の問題 およびその解決策について，平成元年度から平成 2 年度まで 2 か年にわたつて学識者, ジェットフォイ 儿運航船社，造船事業者および関係団体からなる超 高速旅客船夜間航行問題調查検討委員会によって検 討されている。

その結果, 平成 3 年 7 月運輸省より全没翼型水中 翼船の夜間翼走について認可基準が定められ，その 条件を満足すればジェットフォイルの夜間翼走が可 能となった。

各関係者の尽力によって, 平成 3 年 11 月より佐渡 汽船㑣殿にて，夜間の営業航海が開始されている。

\section{9.あとがき}

ジェットフォイルは, 従来の船の概念とは全く異 なった思想のもとに設計・建造された高性能の全没 翼型水中翼船であり，その高速性，快適性，さらに は新奇性の点で際立ったものがある。このジェット フォイルが，船酔いから乗客を開放し，快適な船旅 を約束する “海の新幹線”として時代のニースに応 えていくものと確信する。

\section{考文献}

1）松井，松村，中山，古賀：「析出硬化型ステンレ ス鋼（15-5 PH 鋼）の電子ビーム溶接」第 133 回 溶接法研究委員会資料 (1991 年 7月)

2）鴨井，村上，小島，松村，古賀，中澤，仁瓶，上 門，水田：「超滈速水中翼船用高強度ステンレス 銅の溶接工作法に関する研究」川崎重工技報第 111 号(1991年 10 月)

3）今村, 斉藤, 浅尾, 寺田, 小林, 岩田, 有元：「ジェッ トフォイルの自動姿勢制御システム」川崎重工技 報 第 107 号 (1990年 10 月)

4）岡,斎藤, 黒井：「ハイドロフォイル艇の航走安 全及びその制御」運動性能研究委員会第 6 回シン ポジウム(1989 年 12 月)

\section{各種新材料の溶接接合の問題解決のための情報システム化}

第1日 12 月 8 日（火）

1) 開会の挨拶

$(13: 00-13: 05)$

司会 小林教授

2）話題 1。TMCP 含む新開発鎆と溶接技術

$(13: 05-13: 45)$

新日鉄鉄鋼研接合研究部 堀井行彦

3）話題 2 . 高耐食・高耐熱・高強度ステンレス鎆と溶 接技街

$(13: 45-14: 25)$

住金基礎技術研接合研究室 小川 和博

4）話題 3 。車体軽量化のためのアルミ適用とその溶接 の問題点

$(14: 25-15: 05)$

日軽技研接合研究室 松本 二郎

5）話題 4.チタンおよびチタン合金の適用拡大とその 溶接

$(15: 05-15: 45)$

神戸製鋼エネルギー開発本部製造部広瀬 博章

6）話題 5 .クラッド材料の適用拡大とその溶接

$(15: 45-18: 25)$

NKK 福山研究所鋼材チーム 長江 守康

7) 話題 6 . 宇宙航空材料とその溶接 $(16: 25-17: 05)$

三菱重工名古屋航空宇宙システム 清藤晋一郎
8）第一日の議論のまとめ（司会 百合岡）

$(17: 05-17: 30)$

第 2 日 12 月 9 日(水)

司会 野本教授

9）話題 7。材料と溶接法のデータベース化を考える

( $9: 00-10: 00)$

新日鉄鉄鎆研接合研究部 糟谷 正

司会 百合岡部長

10) 総合討論

話題1-7の講演を中心に，参加者全員による各種材料の 溶接接合について現在抱えている問題点をまとめると共 に，材料とプロセスの情報システム化の将来について討 論します。

11）閉会の挨拶 (11:55-12:00)

(申込先)

干141 東京都品川区北品川5丁目 3-20 愛知産業战 3

階 第 2 エーエスビル

財団法人 溶接接合工学振興会事務局

TEL 03-3449-2144 FAX 03-5488-5520 